\title{
Research on the Training Mode of Applied Talents in Music Education Major in Private Universities
}

\author{
Weihua Xiao ${ }^{1, a^{*}}$ \\ ${ }^{1}$ Nanchang Institute of Science and Technology Nanchang, 330108, China. \\ a79278792@qq.com \\ * The corresponding author
}

\section{Keywords: Music; Reform; Training mode; Applied talents}

\begin{abstract}
In recent years, there is a big gap between the current situation of teaching and the needs of the society. In order to improve the teaching level of higher education in China, we should focus on the reform of the mode of talent training, especially for the major of music and art, and should highlight the cultivation of applied talents. As a product of the popularization of higher education, private undergraduate colleges are a new school running mode of higher education. By combining the current situation and trend of the development of private colleges and universities and the current situation and trend of the development of music education in primary and secondary schools, this paper puts forward some reasonable suggestions and ideas for the development of the training mode of the applied talents of music teachers major in the private colleges and universities in the future. In the future, the development of the training mode of applied talents for music teachers in private colleges and universities must follow the concept of combination of mechanism innovation and characteristic inheritance, localization and diversification, and constantly reform and innovate in practice, so as to constantly improve the training mode.
\end{abstract}

\section{Research Background and Significance}

Research Background. The applied private undergraduate education is a new type of higher education in China in recent years. It has an irreplaceable special position and function in the higher education system of our country. As a product of the popularization of higher education, the private colleges and universities have formed a complementary relationship with a class of two types of colleges and universities. In the training goal of the music teachers' major and the training idea of the applied talents, the particularity of the training of the private colleges and universities is fully embodied in the course setting and teaching links. Under such circumstances, there is a great difference between the teaching of Applied Undergraduate Music and the teaching of professional music colleges. How to jump out from the traditional music teaching mode makes the graduates better adapt to the needs of the society and become the backbone of improving the comprehensive quality of the people, which has become an urgent problem to be solved.

Research Significance. Through the current situation investigation of the training mode of applied talents for music education in private colleges and universities, the particularity of the training mode of applied talents for music education in private colleges and universities is explored, and the training mode of the applied talents of the private undergraduate colleges and universities is perfected by combining the present situation and trend of the development of private undergraduate colleges and universities. It keeps developing and adapting to the needs of applied music talents in the society.

\section{Research Methods}

Investigation Method. By using the current situation investigation, questionnaire survey and interview survey method, we enter into the classroom of applied normal education in private universities, and grasp the first-hand information in depth. The following is a different course classification method to present the basic situation of music teachers' professional curriculum in 
Taizhou College of Nanjing Normal University. This paper analyzes the difference between the curriculum and the public university in Table 1.

Table 1 The basic situation of the curriculum of music education

\begin{tabular}{|c|c|c|c|}
\hline \multicolumn{2}{|c|}{ Curriculum type } & Academic score & Percentage \\
\hline \multirow{2}{*}{ General education } & Required course & 47 & 21.27 \\
\cline { 2 - 4 } & Elective course & 4 & 1.81 \\
\hline \multirow{2}{*}{$\begin{array}{c}\text { Basic subject } \\
\text { course }\end{array}$} & Basic course & 4 & 1.81 \\
\cline { 2 - 4 } & Professional basic course & 31 & 14.02 \\
\hline \multirow{2}{*}{$\begin{array}{c}\text { Teacher education } \\
\text { curriculum }\end{array}$} & Professional trunk & 31 & 14.03 \\
\cline { 2 - 4 } & Professional direction & 17 & 7.69 \\
\cline { 2 - 4 } & Comprehensive practice & 20 & 9.05 \\
\hline \multicolumn{2}{|c|}{ Independent development course } & 67 & 30.32 \\
\hline \multicolumn{2}{|c|}{ Total } & 221 & 100 \\
\hline
\end{tabular}

We can see that the music majors in this university have 221 credits to work together, including basic courses, education courses, compulsory courses and elective courses, which have a reasonable proportion and can be very effective in training the students of the music education major. In Table 1 , we can present the curriculum of music education, and make further analysis here. In order to facilitate the presentation of the credit rating of music majors in Taizhou College of Nanjing Normal University, the above tables are converted to charts.

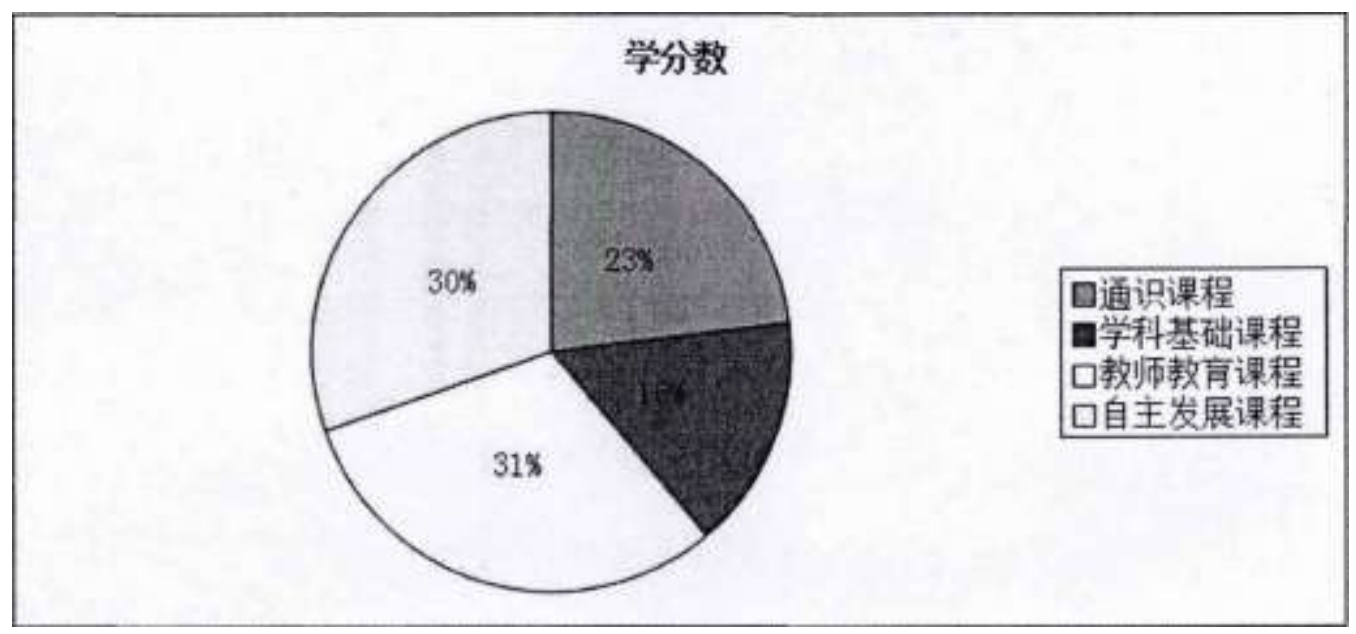

Figure 1. Finite The basic picture of the curriculum of music education

It can be seen from Fig. 1 that the total credits of the teacher education course of the Taizhou College of Nanjing Normal University reflect its teacher's quality. The independent development course credits are higher than the basic courses and the proportion of general courses. To a certain extent, the music teachers' major of the Taizhou College of Nanjing Normal University is shown to the students. The flexibility of choosing courses is aimed at maximizing the advantages of learning first and training them pertinent.

Comparative Law. From the aspects of training concept, curriculum setting and teaching contents, we compare music teachers' majors in one or two kinds of undergraduate colleges. This paper makes a comparison of the music specialty of private colleges and universities in our country, analyzes the typical cases of the training mode of the ordinary university music talents, analyzes and summarizes the current situation and problems of the training of the music talents in the private colleges and universities in our country. 
Educational Statistics. Based on the general principles of education statistics, the proportion of the graduates engaged in primary and secondary school music teachers' occupation was sorted and summarized, and the relevant contents of the training of Applied Music Teachers in private colleges and universities were explored in the questionnaire survey. Statistics and processing the relevant data from the questionnaire apricot table, analyze the data results, explore problems and solve problems.

\section{Reform of Training Mode of Applied Talents in Music Education Major}

Traditional Musicology Education Model and Existing Problems. The traditional music education is to cultivate professional music talents, to possess excellent performance and singing skills, or to have a strong musical theory level, and to engage in theoretical research. The social demand of this kind of elite is not very big. Nowadays, a large number of graduates will not be able to find a job in the continuous enrollment expansion. This needs to reform the original training mode, let the students master some practical application ability and improve the market competitiveness.

The Social Demands for Music Education Talents at the Present Stage. The major of music education in Colleges and universities is to train music teachers in primary and secondary schools. Most of their graduates are engaged in education. The graduates of music education major want to get better job opportunities after graduation and play the music education task of middle and primary school students. They should have the knowledge and ability in the following aspects: (1) Master and apply the basic theoretical knowledge of music education, such as music theory, harmony, musical form analysis, etc. (2) There is a certain ability to play and sing. (3) It has the basic ability of performing music teaching independently, performing singing and singing, and creating practice independently. (4) To understand the principles, policies and regulations of the State concerning the development of music and arts. (5) Understanding the dynamics of music education at home and abroad.

Exploration on the Training Mode of Applied Undergraduate Music Education. (1) Pay attention to the teaching of solfeggio. With the continuous updating of the educational concept, the comprehensive nature of the curriculum is the new requirement of the development of the education situation in recent years. It is the aim of the music education major of the university to cultivate "one special ability" to engage in basic music education. Solfeggio is a very important basic course of music education in Colleges and universities. It is the representation of music theory and professional skills in practice. Therefore, in the process of Solfeggio teaching, we should strengthen mutual connection and mutual penetration between Solfeggio and other courses.

(2) The teaching of basic theory should be diversified. In addition to explaining in class, theoretical teaching should give students more opportunities to practice. Students can perform the accompaniment of their songs and songs in the form of concerts. Diversification of teaching can promote students' interest in learning and lay the foundation for other subjects.

(3) To strengthen the practicality of the dance. In the college music education major, the dance course is short, only teaching students to learn a bit of ballet and dance combination, but in the future work, students deeply understand the importance of dance.

(4) Strengthen team practice. During the University, a variety of bands should be organized to rehearse, such as Orchestra, folk band, chorus and so on, so as to strengthen the team consciousness and cultivate the students' organizational ability in rehearsal.

(5) To increase the practical teaching of the piano. Traditional piano teaching generally focuses on basic skills, and from the scales, etudes to tracks, the purpose is to improve students' piano playing level.

(6) Strengthen the practice of stage performance and teaching. In the music education of colleges and universities, the ultimate aim of the students to master the skills and theoretical knowledge is to apply to the future teaching. Therefore, the students must have the practical experience of the stage performance to better show their own learning results. 


\section{Strategy Conception of Talent Training Mode Development}

Reform of Teaching Idea. At the same time, we should make great efforts to cultivate applied talents, pay attention to the reform of the social and economic system, digest and absorb the previous practical experience, and make use of the pattern changes under the new situation and new challenges at any time. In the future, the music education in primary and secondary schools will integrate the teaching of singing, music and action, improvisation of music and the diversified teaching methods on the basis of the aim of improving the quality of humanistic music in the teaching concept. It is necessary to adjust the concept of training applied talents in private colleges and universities. In the course of training, we should not forget the original intention of education, take each student as the base, and serve the future of the nation as its own standard, not only to meet the development requirements of the social local economy, but also pay more attention to the sublimation of the value of education.

The Sublimation of Teaching Content. There are still some problems in the school music education in our country. It is the main contradiction of the school music education to carry out a more comprehensive and systematic training of music foundation in a solid and effective way. Most of the applied music talents trained by the music teachers' major in the ten private colleges and universities are mostly transported to primary and secondary schools. If the talent training is not combined with the needs of school music education, it is likely to remain in the form but can not solve the actual problems of school music education. The private colleges and universities must follow the trend of the international development of school music education. It should be adjusted and rebuilt by drawing lessons from the contents of foreign advanced educational system and the actual situation of their own schools. Striving to integrate with world music culture, integrate with local music education, and gradually mature from mechanism management to formal content. In the reform of talent training mode, we should carry out a variety of training objectives, diversification of teaching forms, diversification of curriculum and multi dimension evaluation mechanism, and explore a training model suitable for the actual situation of private universities.

The Change of Teaching Methods. Comprehensive use of discussion teaching, case teaching, project teaching, field teaching, carry out all kinds of teaching activities to arouse students' learning enthusiasm, improve students' self-learning ability, make students improve their own practical ability, and the ability to adapt to the circumstances. The classroom is no longer simply a teacher lecturing, students listening to lectures, but discussing knowledge, heuristic knowledge and solving knowledge problems. The music teachers' major in higher education has a "one to one" specialized small class mode. On this basis, we can combine the methods of field teaching. For example, Chinese traditional music appreciation can go out of the classroom and face to the music culture under the conditions allowed. Experience music culture in the sense organ, enhance music accomplishment.

\section{Summary}

The training mode of Applied Talents in music education major in private universities has distinct characteristics, but there are still some problems. The development of characteristic socialist economy has led to the formation and development of private undergraduate colleges and universities. However, it is precisely because of this distinctive feature that the music teachers' major in private colleges and universities, supported by the traditional institutions of higher education, faces special training objects, from the cultivation of ideas to All aspects of curriculum implementation must continue to accept the impact and test of practice. The development of the mode of training applied music talents for music education in private colleges and universities must be based on both innovation and inheritance, and to open up a strategic system which is suitable for the social and economic development of the service and the development of Chinese music education. According to the needs of different levels, the training mode not only adapt to the development of higher education in China, but also highlight the characteristic school running mode of private colleges and universities. 


\section{Acknowledgements}

Funded projects: Nanchang 13th Five-Year (2016) Social Science Planning Project. Subject name: Education of red songs and cultivation of socialist core values - - take the Nanchang Institute of Science and Technology as an example. Subject number: DJ201601.

\section{Reference}

[1] Yousheng Zhang. Research on the theory of sustainable development of higher education[M]. Educational Science Press, 2015.

[2] Zhiqiang Wang. Research on the development mode of independent colleges[M]. University of Electronic Science and technology of China Press, 2013.

[3] Fengzhen $\mathrm{Xu}$. The innovation of the concept of teaching reform and the construction of the model[M]. China Social Science Press, 2015.

[4] Inner Terremer. Philosophy of music education[M]. People's music press, 2013.

[5] Ling Cao. On the cultivation of compound talents in music education[J]. Art education, 2016 (6).

[6] Zhenyu Liu, Yizhi Yu. General situation and Prospect of music education in normal universities in China[J]. Journal of Tianjin Conservatory of Music, 2011 (3).

[7] Jian Feng. Thoughts on curriculum reform of music education in normal universities[J]. Music Exploration, 2013 (1).

[8] Jin Zhang. Reflections on the reform of music education in normal universities[J]. Journal of Sichuan College of Education, 2014 (9).

[9] Li Wang. Practical research on undergraduate applied talents training in northwest ethnic minority areas[D]. Lanzhou University, 2013.

[10]Liang Zhao. Research on the training mode of applied talents training[D]. Southwestern University, 2014. 